821.163.41-1.09 Јовановић, Јован Змај https://doi.org/10.18485/msc.2018.47.2.ch37

Јован М. ЉУШТАНОВИЋ*

Висока школа струковних студија

за образовање васпитача

Нови Сад
Оригинални научни рад

Примљен: 19. 11. 2017.

Прихваћен: 27. 12. 2017.

\title{
ЕЛЕМЕНТИ КАРНЕВАЛИЗАЦИЈЕ У САТИРИЧНОЈ ПОЕЗИЈИ ЈОВАНА ЈОВАНОВИЋА ЗМАЈА
}

\begin{abstract}
Рад се бави елементима карневализације у сатиричној поезији Јована Јовановића Змаја. Централни проблем овог истраживања је питање изведено из теорије карневализације М. Бахтина: колико сатира може да изрази „целовитост смеховног аспекта света”. Показује се да Змај има знатан број песама које су везане за актуелне политичке и социјалне догађаје и снажно су усмерене на детронизацију предмета подсмеха. Такве песме припадају „чистој сатири” и не остварују карневалски „смех целог света”. Ипак, открива се и читав низ песама у којима је развијена хумористичка игра и у којима се остварују карневалске инверзије високомиметског у нискомиметско. У тој поезији конкретизују се и театрализују апстрактни догађаји и односи и видно је присуство чулног и телесног. У њој су присутне пародија и гротеска и укрштање различитих језичких, често колоквијалних, речи и идиома. Такве се песме приближавају Бахтиновој универзалности „смеховног аспекта света”. Истовремено се наговештава да је културна и историјска ситуација у којој ствара Змај битно различита од оне културне ситуације касног средњег века и ране ренесансе коју описује Бахтин. У Змајевој сатиричној поезији елементи карневализације бивају ресемантизовани и уклопљени у српску грађанску културу XIX века.

Кључне речи: детронизација, игра, карневализација, поезија, сатира, смех, универзално, Јован Јовановић Змај, српски романтизам.
\end{abstract}

Смисао теме којом се овом приликом бавимо, може се, с добрим разлозима, ставити под сумњу. Чини нам се да су карневализација и сатира, онако како их описује М. Бахтин, појмови који се међусобно искључују. Карневализација почива на начелу универзалности: smeju se $s v i$, to je smeh 'sveg sveta', drugo, on je univerzalan (наглашавања М. Б.), on je usmeren na sve i svakog (pa i na same učesnike karnevala), ceo svet je predstavljen kao smešan (Бахтин 1978: 19). Насупрот томе, Бахтин за сатиру неувијено каже:

\footnotetext{
*joljilja@gmail.com
} 
Čist satiričar, koji zna samo za negativan smeh, stavlja sebe izvan pojave kojoj se podsmeva, suprotstavlja sebe njoj, i time razbija celovitost smehovnog aspekta sveta, smešno (negativno) postaje pojedinačna pojava. Ambivalentni narodni smeh izražava gledište čitavog sveta u nastajanju, kojem pripada (Бахтин 1978: 19).

Ипак, ово Бахтиново јасно и одлучно изопштавање сатире из карневалске смеховне културе има и своје „зоне неодређености”. То нам омогућује да поставимо питање о елементима карневализације у сатиричној поезији Јована Јовановића Змаја.

Прво, Бахтин негативно говори само о „с̆іstoj satiri”, остављајући тиме могућност за одређене сатиричке функције саме карневализације. Он те функције, на различите начине, више пута спомиње. На пример, он види амбивалентност карневалског смеха. Тај смех, колико је „veseo i likujući”, толико је и „podrugljiv i ismevački” (Бахтин 1978: 19), самим тим и сатиричан. Друго, Бахтин ни „чисту сатиру” не искључује потпуно из смеховности, без обзира на то што она „razbija celovitost smehovnog aspekta sveta”. Слути се да је, ипак, могуће сатиричну поезију уопште, па и Змајеву, сагледавати у кључу Бахтинове теорије карневализације, и то тако што би се поједине песме откривале као дела привремене, привидне или неуспешне сатиричке парцијализације, односно као дела која својом смеховном функцијом проналазе начина да се реинтегришу у свеопшту карневалску смеховност.

Једно од битних питања, које је на неки начин отворено и Бахтиновом синтагмом „с̌ista satira”, а које се и те како тиче Змајевог књижевног опуса, јесте шта је то сатира уопште. На први поглед, на њега је лако одговорити. Већ овлашан и скоро насумичан поглед на речнике и појмовнике показује нам, барем на први поглед, сву јасноћу овога појма. На пример, у Речнику књижевних термина се каже:

Satira je književno delo u kojem je na podrugljiv i duhovit način izražena oštra osuda jednog društva ili ljudskih mana. Njen osnovni cilj je da ukaže na društvene ili moralne slabosti, poroke i zloće, da ih izvrgne ruglu i podsmijehu i da na taj način doprinese njihovom otklanjanju (Лешић 1985: 694).

Ово одређење јасно указује на предмет сатире: „društvene ili moralne slabosti, poroke i zloće”. Начини на које се сатира односи према предмету по овој дефиницији јесу „подругљивост” и „духовитост”. Гледано из хоризонта теорије смешног оба појма имају одређену легитимност. „Smeh je, takoreći, kategorički pluralitet, njegovo objašnjenje je uvek u međuprostoru predmeta i subjekta" (Перишић 2010: 22). Шта се догађа у том међупростору када је реч о сатири? Несумњиво је да сатирички субјекат хоће да снажно маркира свој предмет. То издвајање јесте, пре свега, аксиолошки удар на предмет, поступак снажне детронизације. Притом, ако „подругљивост” носи тај удар, „духовитост" не мора бити инструмент радикалне детронизације. По појединим теоријама смеха, да би се неко смејао, потребна је хумористичка припрема, потребно је конституисање „духовитости” у језику и у комуникацији. С. Фројд у својој теорији досетке (Witz), каже да ,pre svake dosetke postoji nešto što možemo označiti kao igru ili šalu" (Фројд 1969: 132). Та игра и шала се 
често, на микроплану, препознају у језику: као хиперболе, градације, контрасти, лексичка и гласовна нагомилавања, паралелизми и различити облици понављања, али и на макроплану као уланчавање смеховних јединица, као стварање особене смеховне партитуре (в. Бергсон 1993: 34). Притом се разлика између „подругљивости” и „духовитости” може интерпретирати и као разлика између снажне заокупљености предметом (под)смеха и заокупљености хумористичком игром. И сам Бахтин на више места истиче игру као суштину карневала: „Dakle, u karnevalu sam život igra, a igra privremeno postaje sam život. U tome je specifična priroda karnevala, posebnost njegovog bića" (Бахтин 1978: 15).

Другим речима, Бахтинова теорија карневализације не одбацује грубо изругивање, напротив, она би пре могла замерити „чистој сатири” опседнутост конкретним предметом детронизације и недовољно присуство игре као медијума у коме се остварује карневал.

Сатирична поезија Јована Јовановића Змаја посебно је изазовна за промишљање у овом контексту. Змај је био „песник акције, националне и политичке" (Скерлића 1914: 298). Покретао је, уређивао и својим прилозима, у приличној мери, попуњавао листове: Комарач, Змај, Жижа, Стармали (излази тринаест година, 410 бројева), што је све доказ његове изузетне хумористичке, сатиричне и политичке песничке делатности. Описујући Змајеве прилоге у првом листу ове врсте, Комариу, али и основни правац у уређивању потоњих листова, Д. Иванић каже: „Духовитост, борбеност, политичка досљедност, инвентивност и бескомпромисност на страни добра, слободе и ослобођења српског народа, уз актуелност садржине, основне су одлике Змајевих прилога" (Иванић 2005: 7). По броју прилога, по сатиричкој ангажованости и инвенцији Змај је, вероватно, наш највећи сатирични песник. Његова сатирична, хумористичка и политичка поезија, према грубим проценама, обухвата преко 2000 песама. ${ }^{1}$ Она није довољно истражена и отвара читав низ поетичких, жанровских, културноисторијских питања која истрајавају до данас.

Деценијама је Јован Јовановић Змај био чврсто везан за политички програм Светозара Милетића и за његову политичку странку. Добар део своје енергије, па и песничког умећа, трошио је на текуће политичке обрачуне, при чему се снажно усредсређивао на предмет детронизације, често потчињавајући том импулсу саму хумористичку игру. Притом, он је ангажовано коментарисао збивања на целом српском политичком простору, укључивши у то и политичка збивања у Србији. Ево како, на пример, пева поводом монтираног судског процеса који је у Србији вођен против политичких противника кнеза Михаила 1864. године. У песми „Црна година” (Јовановић 1969а: 122) нигде се не спомињу ни кнез, ни суд, ни процес, ${ }^{2}$ али је алузија за савре-

\footnotetext{
${ }^{1}$ Ивана Вулетић је пребројала укупно 4152 Змајеве песме (1985: 207), од тога је, вероватно, барем половина политичких и сатиричних песама.

2 Сазнање на шта се односи песма дугујемо белешци приређивача Живана Милисавца (19696: 288).
} 
менике била више него јасна. Све је исказано директним и немилосрдним језиком:

Кукавице, варалице, поткупљиви смраде. А зар тако ратоборци будућности раде!

Саможивици, тврдоглавци, надувени црве,

Ви л’ би хтели да с' бројите међу наше прве!

Дукатовци, готовани, чанколизи, мрави -

Камо паклу врела злата, тим да вас задави!

Ово је дезавуисање без милости. Иза њега стоји морални став и политички либерализам самога Змаја. С. Гордић ће у овим стиховима препознати „бујну сликовитост у негативним моралистичким метафорама” и „звучно оркестроване сликовне спојеве перцепције са апстракцијом" (Гордић 1975: 19). Та сликовитост се може, свакако, посматрати као врста песникове не само сатиричне већ и естетске стратегије, али у тој „бујности” има много више обрушеност на предмет детронизације него игре. И данас, када смо из свести изгубили непосредан политички контекст ове Змајеве песме, пажњу заокупља, пре свега, њена „негативна енергија”.

На другој страни, можемо пронаћи код Змаја и песме које су, такође, везане за актуелне политичке догађаје свога времена и данас нам мало значе, али, ипак, преносе до нас песничку енергију која се може повезати с карневализацијом.

На пример, године 1884. долази до раслојавања у политичкој странци С. Милетића. Део српских представника у Угарском сабору прихвата сарадњу с угарским властима. Они држе конференцију српских нотабилитета прво у Пешти, па у Великој Кикинди. Информације о конференцијама се крију и оне споро стижу до Заставе, гласила које је било везано за Милитећа и његову политику. Змај је певао о обе конференције, али је посебно занимљива песма о под насловом „Још се не зна шта је” (Јовановић 1969а: 122) о конференцији у Великој Кикинди:

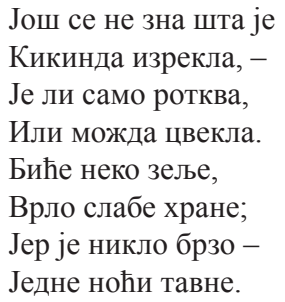

Сатирична детронизација великокикиндске конференције у овој песми изведена је алегоријом из домена хране. Свођење конференције, која је имала претензију да буде скуп угледника (нотабилитета), и њених одлука на „роткву или цвеклу” јесте немилосрдан сатирични удар. Међутим, хумористичко сатирична игра се наставља, развија се нека врста антиклимакса, па одлуке овог скупа оглашавају се „неким зељем”, да би на крају биле именоване као „слаба храна”. Прехрамбено-повртарски „објективни корелатив” у овој пе- 
сми служи да би се превео високомиметски (политички и социјални) садржај у нискомиметски, везан за трбух и уопште са доњи део тела. То превођење, несумњиво, има сатиричну функцију, али оно плени својом хумористичком игром и примицањем карневалском модусу и данас, када су сукоби у странци Светозара Милетића мало позната историјска чињеница из прошлих времена.

Ово су, углавном, мање познате Змајеве сатиричне песме, и то песме које су своју сатиричну оштрицу истрошиле, углавном, у времену у коме су настале. Оне показују различит однос према књижевним и социјално-културним структурама које Бахтин описује у својој теорији карневализације. Међутим, сматрамо да Змај има низ песама које се, упркос својој снажној сатиричној функцији, знатно више приближавају Бахтиновој идеји карневализације.

Као пример можемо узети једну од најчувенијих Змајевих сатиричних песама „Јутутунску јухахаху” (19696: 69-70). ${ }^{3}$ И њен настанак везан је за конретан друштвени и политички повод. Она је најнепосредније била уперена против кнеза Михаила Обреновића који је увео „апсолутистички и лични режим у Србији”, не испунивши обећање да ће ,закон бити највећа воља у Србији" (Милисавац 1969в: 272). Из саме песме се види да је сатирична оштрица уперена против владара који обећава народу устав, под условом да народ буде послушан, веран и плаћа порез. Тај однос је, за потребе сатиричне интерпретације, екстрахован из сложене социјалне стварности, приказан у оштрим контурама - јасно је издвојен предмет подсмеха. Већ то издвајање има и своју карневалску димензију. Краљ Балакаха из Змајеве песме пење се с пролећа на брег и громогласно, целом народу, извикује своја обећања. Реч је о некој врсти чулне конкретизације, упризорења социјално-политичког односа. У песми све бива театрализовано, претворено у неку врсту гротескног перформативног чина. Вероватно, С. Гордић мисли на такав поступак када говори о „лилипутанско-гуливерској зачудности” Змајеве песме и препознаје у њој слику „ритуалног, стравично-комичног деспотизма и подаништва” (1975: 22). ${ }^{4}$

Песма је, гледано у целини, сатирична алегорија. Алегоријски механизам се успоставља тако што се предмет сатиричног удара, кроз карневалску игру, маскира непостојећим речима чији еуфонијски карактер замењује њихово значење. Карневалска лексика коју за ову прилику ствара Змај детронизује озбиљне социјалне и политичке појмове: државу, владара, устав, порез, замењујући их речима састављеним од низа истих или сличних слогова, речима које највише подсећају на изразе раздраганости мале деце, које Корнеј Чуковски назива екикики (в. Чуковски 1986). Притом, новоизмишљене речи речи, у Змајевој игри, постају и различити видови ономатопеје смеха. Имена земље Јутутутуту и народа Јутутунци, иако су изграђена на еуфонијској игри и, тиме, пародична, не садрже непосредно ономатопеју смеха, али већ име

\footnotetext{
${ }^{3}$ Песма има поднаслов „По Гласбренеру”, међутим, до сада није пронађен непосредан немачки узор (в. Миловић 1986: 264).

${ }^{4}$ Нема сумње, „Јутутунска Јухахаха” могла би се сматрати неком врстом претходнице оног упризорења Жаријевог Краља Ибија, које је играно, у режији љ. Драшкића, на сцени Атељеа 212 поткрај шездесетих година XX века.
} 
краља Балакаха јасно је наговештава, док лажно обећани устав - јухахаха - и порез који плаћају поданици - јухухуху - постају средишне тачке сатиричног удара и саздане су, пре свега, од ове ономатопеје. С. Гордић и ову гласовну игру чита као превасходно сатиричну: „Ваљда се ничим другим сем овим фоничким спојем поновљених слогова, тамних вокала, веларних и експлозивних консонаната не може овако магијски дочарати сатрапски деспотизам и подаништво” (Гордић 1975: 23).

Овакво читање сатиричке функције еуфонијског слоја у „Јутутунској Јухахахи" не противречи препознавању карневалске игре у њој. Очигледно, у овој песми сатирично и игровно нису међу собом супротстављени, не ограничавају се и не искључују међусобно, напротив - развијена хумористичка игра и сатирична детронизација међусобно се подупиру. Чулна конкретизација, гротескна театралност појединих слика, пародична функција речи и израза и пародичност целе песме, звучна експресивност појединих речи, инверзија високомиметског у нискомиметско, све се то може, на овај или онај начин, довести у везу с Бахтиновим схватањем карневализације. Томе доприноси и чињеница да је Змај у овој песми ухватио вечиту напетост између оних који имају политичку моћ и хоће да максимално узурпирају власт и оних који жуде за законитошћу, правдом и остварењем права. Отуда у њој уз универзалност игре постоји и универзалност сатиричке функције, што омогућава трајнију и хумористичку и сатиричку актуелност песме, приближавајући је Бахтиновом смеху „целог света”.

Управо је „Јутутунска јухахаха” пример како сатирична песма, без обзира на снажну усредсређеност на предмет подсмеха, може, захваљујући развијености и карневалским типовима хумористичке игре и социјалној истрајности предмета сатиричног удара, досећи универзални дух карневализације. Та формула, на овај или онај начин, истрајава и у низу других Змајевих сатиричних песама.

Посебно је с те стране занимљива Змајева песма „Устарабари” (Јовановић 1969а: 163-165). Већ наслов песме садржи у себи елементе карневализације, јер је вид људског понашања - бескичмењаштво, бескарактерност и политички опортунизам - метафорички представљен чулно конкретном сликом људи који се непрестано држе уз тарабу. И ова Змајева песма садржи низ алузија на савремене политичке догађаје, али она, независно од тога, жигоше карактерну ману која истрајава у различитим историјским временима и траје до данас. Сем тог облика универзалности, ова Змајева песма садржи развијену хумористичку игру која на различите начине кореспондира с Бахтиновим схватањем карневализације.

Пре свега, у песми је садржан необичан пародички поступак. Песма има мото на немачком језику који је пародија Шилерових стихова упућених Русоовом гробу. Шилер у својим стиховима више пута и на различите начине спомиње срам и писање о срамоти (Schande и Scmachschrift), метафорично истичући морални учинак филозофског дела који се остварује и после Русоове смрти. Змај користи Шилерову лексику, замењујући поједине појмове сродним, али, ипак, различитим речима, па оно што је код Шилера било „пи- 
сање о срамоти” постаје само „срамота” (Scmachschrift постаје Scmach), и тиме мења смисао, а срамоту везује за устарабаре. Најрадикалнија Змајева интервенција јесте уношење речи „устарабари” у немачке стихове. Српска ћирилична реч и графички одудара од немачког текста, чиме мото песме у пуној мери постаје „,parodijsko smehovno delo” у духу Бахтиновог схватања карневализације (в. Бахтин 1978: 10). Поједини Шилерови стихови, са Змајевим пародијским варијацијама, бивају уклопљени у ткиво песме.

Песма садржи и неке друге елементе карневализације. Њена универзална интенција није само смеховна и сатиричка, она пева о свету који се мења, насупрот истрајности устарабара и устарабарства. Сем тога, у песми је исприповедана анегдота која је прича о маскенбалу (карневалу), тако да у песми која је већ донекле карневализована срећемо опис карневала. Анегдота је алегорија на понашање и социјални положај устарабара. Она прича о Турчину који је успео да наговори неку децу да се преруше у робље и пођу с њим на маскенбал. На балу их је богато почастио, али је у салату усуо рицинус. Турчин везује своје робље и онда бежи. Настаје смешна ситуација у којој деца изложена погледима „час дигну једну, час другу ногу”. У овој анегдоти Змај дотиче скатолошки аспект карневализације, прави смешну слику у којој важно место заузима доња половина људског тела, црева и њихово пражњење.

Више је сатиричних слојева у овој песми. Између осталог, у причи о Турчиновој подвали, о робљу које је пристало на игру, о његовом срамотном положају на крају песме, садржана је алузија на положај Срба у крајевима који су још под Турцима и на моралну беду подаништва. Упркос томе, ова песма привлачи пажњу и постиже своју универзалност, колико предметом сатиричке детронизације, толико маштовитом и разноликом хумористичком игром.

Круг Змајевих сатиричних песама у које у највећој мери продире дух карневализације јесу постиљонске оде. ${ }^{5}$ Ове, у огромном Змајевом песничком опусу недовољно примећене песме, нашле су се пред савременим читаоцима захваљујући приређивачком напору М. Клеут (в. Јовановић 2003). Пародичност, тематика и однос према језику и, када се све сабере, њихова способност да досегну универзалност карневалског смеха, могу се с разлогом сматрати елементима који повезују овај круг Змајевих песама с Бахтиновим схватањем карневализације.

Пре свега, постиљонске оде су, што се слути из заједничког назива, али и из њихових појединачних наслова - пародије. Змај пародира класицистичку оду, свечану, похвалну песничку врсту, која је у српској, али и у руској и немачкој класицистичкој књижевности, била једна од најраспрострањенијих и најзначајних песничких врста (в. Павић 1979: 359-365). Ода се, управо због своје класицистичке етаблираности, нашла „на линији ватре” у текућим књижевним полемикама у склопу промене парадигми у српској књижевности и култури прве половине XIX века (Вукове реформе и ступање роман-

\footnotetext{
5 Заједнички именитељ ових хумористичко-сатиричних песма је Змајев (в. Клеут 2003: 76).
} 
тичарске поетике на културну позорницу). Пре Змаја класицистичку оду је пародирао Бранко Радичевић у сатиричној поеми „Пут” и то оду „Моја Муза" Милоша Светића (Јована Хаџића), што је био својеврстан допринос „младог Вуковог приврженика” Вуковој полемици с Хаџићем (в. Клеут 2003: 79). Због тога је Радичевићева пародија блиска „чистој сатири”, јер снажно изоштрава предмет подсмеха. Змај се тридесетак година доцније подсмева песничком маниру и поетичком мишљењу који су били довољно познати и културно етаблирани да би њихово изокретање и травестија изазивали смех, али, предмет његовог смеха није сужен и истакнут као Бранков, Змајев смех је ближи смеху „целог света”.

Ода је, у складу с класицистичком поетиком, припадала „виском стилу”, а Змај ће, „уз привидно поштовање норми високог стила, свим расположивим поетским средствима, довести свечану и озбиљну песму у позицију ниског стила, и на том контрасту изградити хумористичке ефекте" (Клеут 2003: 81). Змајева инверзија, управо на тематском плану, узвишене предмете похвале замењује не само тривијалним, свакодневним појавама и чињеницама, већ су њени супститути везани за тело, задовољство, храну, доњу човекову половину, чиме се остварује „krajnja prevlast materijalno-telesnog načela života” (Бахтин 1978: 26). Када Змај узвикне „Ој, трбуше, владаоче света” (Змај 2003: 12) он као да кличе, у карневалској поворци, новом краљу карневала, који је својом плотском страном супротност озбиљном устројству света и његовим владаоцима. И уистину, већ наслови појединих Змајевих ода јасно наговештавају карневалски, телесни, претежно прехрамбени предмет његовог певања: „Господару трбуху” (Јовановић 2003: 12-13), „Ода киселој чорби” (Јовановић 2003: 14-17), „Ода мојој чутури” (Јовановић 2003: 22-23), „Ода црвеном носу” (Јовановић 2003: 39-41), „Ода глади” (Јовановић 2003: 49-52), „Ода кечиги” (Јовановић 2003: 62-64). У свим овим песмама страст за јелом и пићем и, уопште, људска облапорност, у карневалском духу, изједначава различите социјалне слојеве, професије и сталеже. Притом, у хумористичкој интертекстуалној игри предмет пародичне детронизације постаје цео књижевни пантеон, од Библије до класика светске књижевности (на пример, немачки песник Шилер бива у „Оди црвеном носу” упоређен с омиљеним сремским вином шилером).

Змајева употреба језика у постиљонским одама, као и у многим другим сатиричним песмама, такође има сличности с употребом језика на карневалу. То нису увек „različite forme i žanrovi slobodnog uličnog govora” (Бахтин 1978: 10), али, без обзира на то, избор лексике „изузетно је битан за хумористичке ефекте у Змајевим постиљонским одама" (Клеут 2003: 85). Змајева лексика и фразеологија експресивна је, често изненађујућа и ремети постојећи мисаони и језички поредак попут уличног говора на карневалу. Змај у својој хумористичкој игри меша више језика и дискурса, „сем сувременог књижевног српског ту су: дијалектизми, неологизми, речи из српскословенског, славеносерпског, латинског, немачког, мађарског, пољског и француског” (Клеут 2003: 85). Све те речи и изрази у Змајевој поезији гомилају се на малом језичком простору, додирују се, међусобно повезују и контекстуализују, али 
и супростављају једна другој. Та мешавина „често прелази у макаронизам” (Клеут 2003: 85). Змајева употреба језика у великој мери је израз смеховне разиграности блиске карневалској језичкој разузданости.

Укупно гледано, Јован Јовановић Змај, својом сатиричном и хумористичком поезијом, велики је логотет српске смеховне културе. Ипак, Змајев однос према смеху, колико год то био у појединим својим аспектима „смех свег света", дубоко је укорењен у српској грађанској култури XIX века. Нити је Змај Франсоа Рабле, нити је Змајево време позни средњи век, нити су у српској култури упражњаване карневалске свечаности какве описује Бахтин. Змајева сатирична поезија често се бавила свкодневним политичким и друштвеним догађајима који су нама данас често непознати, или нам се чине ситним и безначајним. Све се то одигравало, пре свега, у шаљивим листовима које је уређивао и добрим делом попуњавао Ј. Ј, Змај. Ти листови, попут Стармалог, у коме су, уз шалозбиљье прилоге, какви су биле Змајеве сатиричне песме, објављивани и различити песнички и прозни хумористички прилози (в. Иванић 2005) - били су медијуми српске грађансе смеховне културе свога времена. Они су, што се широке и разнолике смеховности тиче, били савремени грађански пандан средњовековног карневала. Тај пандан је створио, пре свих, J. Ј. Змај.

\section{ЛИТЕРАТУРА}

Бахтин 1978: M. Bahtin, Stvaralaštvo Fransoa Rablea i narodna kultura srednjega veka i renesanse, Beograd: Nolit.

Бергсон: 2004: A. Bergson, O smehu, Novi Sad: Vega media.

Вулетић 1985: I. Vuletić, Metrički registar pesništva Jovana Jovanovića Zmaja, u: S. Petrović (ur.), Zmajev stih, Radovi sa stručnog radnog sastanka održanog u Novom Sadu održanog 5. i 6. decembra 1985, Novi Sad: Vojvođanska akademija nauka i umetnosti.

Гордић 1975: С. Гордић, Структурални и стилски аспекти Змајеве сатиричне поезије, Београд: Књижевност и језик, XXII/1, [13]-25.

Иванић 2005: Д. Иванић, Стармали Јована Јовановића 3маја: студија [u] избор текстова, Београд: Библиотека града Београда.

Јовановић 1969а: Ј. Ј. Змај, y: Ж. Милисавац (прир.), Политичке и сатиричне песме I, Нови Сад: Матица српска.

Јовановић 1969б: Ј. Ј. Змај, y: Ж. Милисавац (прир.), Политичке и сатиричне песме II, Нови Сад: Матица српска.

Јовановић 2003: Ј. Ј. Змај, Гледајући Нови Сад, Постиљонске оде Јована Јовановића Змаја, пр. Марија Клеут, Нови Сад: Матица српска, Змај.

Клеут 2003: Марија Клеут, Постиљонске оде Јована Јовановића Змаја, $y:$ Гледајући Нови Сад, Постиљонске оде Јована Јовановића Змаја, Марија Клеут (пр.), Нови Сад: Матица српска, Змај, 75-90.

Лешић 1985: Z. L[ešić], Satira, Rečnik književnih termina, Beograd: Nolit, 694-697. 
Милисавац 1969а: Ж. Милисавац, Политичка ангажованост песника Змаја, J. J. Змај, y: Ж. Милисавац (пр.), Политичке и сатиричне песме I, Нови Сад: Матица српска, 7-52.

Милисавац 1969б: Ж. Милисавац, Коментари и тумачења речи, Ј. Ј. Змај, y: Ж. Милисавац (пр.), Политичке и сатиричне песме I, Нови Сад: Матица српска, 283-315.

Милисавац 1969в: Ж. Милисавац, Коментари и тумачења речи, Ј. Ј. Змај, y: Ж. Милисавац (пр.), Политичке и сатиричне песме I, Нови Сад: Матица српска, 263-302.

Миловић 1986: Ј. М. Миловић, Јован Јовановић Змај и њемачка књижевност, Титоград: НИО Универзитетска ријеч.

Павић 1979: М. Павић, Историја српске књижевности класицизма и предромантизма, Класииизам, Београд: Нолит.

Перишић 2012: I. Perišić, Uvod u teoriju smeha, Beograd: Službeni glasnik.

Скерлић 1914: Ј. Скерлић, Историја нове српске књижевности, Београд: Издавачка књижара С. Б. Цвијановић.

Фројд 1969: S. Frojd, Dosetka i njen odnos prema nesvesnom, Novi Sad: matica srpska, 1969.

Чуковски 1986: К. Čukovski, Od druge do pete, Beograd: Zavod za udžbenike i nastavna sredstva.

Jovan M. Ljuštanović

ELEMENTS OF CARNIVALIZATION IN SATIRIC POETRY OF JOVAN JOVANOVIĆ ZMAJ

(Summary)

The paper deals with the elements of carnivalization in the satiric poetry of Jovan Jovanović Zmaj. The central problem of this research is the question derived from the theory of carnivalization of Mihailo Bakhtin: how much satira can express the "integrity of the humorous aspect of the world". It is shown that Zmaj has a considerable number of poems that refer to current political and social events and are strongly focused on the detonation of the subject of mockery. Such poems belong to "pure satire" and do not realize the carnival "laughter of the whole world". Nevertheless, there is revealed a whole series of poems in which a humorous play is developed and where carnival inversions of highvisibility are performed in low-light. In this poetry, the abstract events and relations are concretized and theatralized, and the presence of the sensory and the physical is evident. It contains parody and grotesque and merges various linguistic, often colloquial, words and idioms. Such songs are approaching Bahtin's universality of the "laughing aspect of the world". At the same time, it is suggested that the cultural and historical situation in which Zmaj was writing is essentially different from that of the late middle ages of the early Renaissance, described by Bakhtin. In Zmaj's satirical poetry, the elements of carnivalization are resemantized and incorporated in the Serbian civic culture of the XIX century. 